\title{
Anaemia, iron homeostasis and pulmonary hypertension: a review
}

\author{
Thomas Sonnweber $^{1}{ }^{10} \cdot$ Alex Pizzini $^{1} \cdot$ Ivan Tancevski ${ }^{1} \cdot$ Judith Löffler-Ragg ${ }^{1} \cdot$ Günter Weiss $^{1,2}$
}

Received: 28 October 2019 / Accepted: 28 January 2020 / Published online: 10 February 2020

(c) The Author(s) 2020

\begin{abstract}
Anaemia is a highly prevalent condition, which negatively impacts on patients' cardiovascular performance and quality of life. Anaemia is mainly caused by disturbances of iron homeostasis. While absolute iron deficiency mostly as a consequence of chronic blood loss or insufficient dietary iron absorption results in the emergence of iron deficiency anaemia, inflammation-driven iron retention in innate immune cells and blockade of iron absorption leads to the development of anaemia of chronic disease. Both, iron deficiency and anaemia have been linked to the clinical course of pulmonary hypertension. Various mechanistic links between iron homeostasis, anaemia, and pulmonary hypertension have been described and current treatment guidelines suggest regular iron status assessment and the implementation of iron supplementation strategies in these patients. The pathophysiology, diagnostic assessment as well as current and future treatment options concerning iron deficiency with or without anaemia in individuals suffering from pulmonary hypertension are discussed within this review.
\end{abstract}

Keywords Anaemia $\cdot$ Pulmonary hypertension $\cdot$ Iron deficiency $\cdot$ Cardiovascular disease $\cdot$ Hypoxia

$\begin{array}{ll}\text { Abbreviations } \\ \text { ACD } & \text { Anaemia of chronic disease } \\ \text { AI } & \text { Anaemia of inflammation } \\ \text { BMP } & \text { Bone morphogenetic protein } \\ \text { BMPR2 } & \text { Bone morphogenetic protein type-II } \\ & \text { receptor } \\ \text { CHF } & \text { Congestive heart failure } \\ \text { CTEPH } & \text { Chronic thromboembolic pulmonary } \\ & \text { hypertension } \\ \text { DMT1 } & \text { Divalent metal transporter 1 } \\ \text { DPG } & \text { Diastolic pressure gradient } \\ \text { EPO } & \text { EPO } \\ \text { ERFE } & \text { Erythroferrone } \\ \text { ESC } & \text { European Society of Cardiology } \\ \text { ERS } & \text { European Respiratory Society } \\ \text { Fe } & \text { Iron } \\ \text { FeTf } & \text { Iron loaded transferrin } \\ \text { FPN1 } & \text { Ferroportin 1 } \\ \text { FTN } & \text { Ferritin }\end{array}$

Günter Weiss

guenter.weiss@i-med.ac.at

1 Department of Internal Medicine II, Medical University Innsbruck, Innsbruck, Austria

2 Christian Doppler Laboratory for Iron Metabolism and Anaemia Research, Medical University Innsbruck, Innsbruck, Austria
GDF15 Growth differentiation factor 15

KC Keratinocyte chemoattractant

LAST1 HIPPO central component large tumour suppressor 1

HAMP Hepcidin antimicrobial peptide

HCP 1 Heme carrier protein 1

HFE Human hemochromatosis gene

HGF Hepatocyte growth factor

HIF Hypoxia-inducible factor

HMOX1 Heme-oxygenase 1

HPAH Heritable pulmonary arterial hypertension

HRG1 Haem transporter 1

ICAM1 Intercellular adhesion molecule 1

IDA Iron-deficiency anaemia

IL1 Interleukin 1

IL6 Interleukin 6

IL10 Interleukin 10

IPAH Idiopathic pulmonary arterial hypertension

dPAP Diastolic pulmonary arterial pressure

mPAP Mean pulmonary arterial pressure

MIF Macrophage migration inhibitory factor

MPS Mononuclear phagocyte system

MyD88 Molecular adaptor myeloid differentiation primary response protein 88

NF-kappaB Nuclear factor kappa-light-chain-enhancer of activated B-cells

NTBI Non-transferrin bound iron 


$\begin{array}{ll}\text { PAH } & \text { Pulmonary arterial hypertension } \\ \text { PASMCs } & \text { Pulmonary artery smooth muscle cells } \\ \text { PAWP } & \text { Pulmonary arterial wedge pressure } \\ \text { PH } & \text { Pulmonary hypertension } \\ \text { PDGF-BB } & \text { Platelet-derived growth factor-BB } \\ \text { PVR } & \text { Pulmonary vascular resistance } \\ \text { RNS } & \text { Reactive nitrogen species } \\ \text { ROS } & \text { Reactive oxygen species } \\ \text { SMAD } & \text { Small mothers against decapentaplegic } \\ \text { SOD2 } & \text { Mitochondrial superoxide dismutase 2 } \\ \text { STAT3 } & \text { Signal transducer and activator of transcrip- } \\ & \text { tion } 3 \\ \text { sTFR } & \text { Soluble transferrin receptor } \\ \text { sTFRF } & \text { Soluble transferrin receptor log ferritin } \\ & \text { index } \\ \text { TGFbeta } & \text { Transforming growth factor-beta } \\ \text { TNFalpha } & \text { Tumour necrosis factor-alpha } \\ \text { TSAT } & \text { Transferrin saturation } \\ \text { VCAM1 } & \text { Vascular cell adhesion molecule 1 } \\ \text { VEGF } & \text { Vascular endothelial growth factor } \\ \text { WHO } & \text { World Health Organization } \\ \text { WSPH } & \text { World Symposium on Pulmonary } \\ & \text { Hypertension } \\ \text { ZIP14 } & \text { Solute carrier family 39 zinc transporter }\end{array}$

\section{Introduction}

Anaemia is one of the most important health problems worldwide. It is associated with physical and mental developmental disorders, impaired cardiovascular performance along with reduced quality of life and often linked to increased morbidity and mortality specifically as a comorbidity across a vast range of disease entities [1-3]. Anaemia affects up to $25 \%$ of the world's population with vast locoregional differences. Pre-school children, pregnant and premenopausal women, elderly and individuals contracted with chronic diseases are at a higher risk $[1,2]$. The majority of all cases of anaemia are caused by imbalances of iron homeostasis, given that iron is essential for the formation of haemoglobin. The underlying problem is the insufficient availability of iron for erythropoiesis, which can be caused by two different mechanisms, absolute and/or functional iron deficiency (ID). Absolute ID causes iron deficiency anaemia (IDA), the most frequent form of anaemia, whereas functional ID leads to the development of anaemia of chronic disease (ACD), the second most frequent cause of anaemia in the world [1,2].

Recently, the association of anaemia, altered iron homeostasis and the pathobiology of various forms of pulmonary hypertension $(\mathrm{PH})$ have attracted attention, because treatment of ID with or without anaemia in PH related diseases including congestive heart failure improved patients` exercise tolerance, quality of life, hospitalization rates and mortality [4-6]. We herein shed light on the complex interaction of iron homeostasis, anaemia and $\mathrm{PH}$, and aim to give guidance on how to select $\mathrm{PH}$ patients who might benefit from iron supplementation.

\section{Disorders of iron homeostasis and anaemia}

Iron $(\mathrm{Fe})$ is an essential element of life, which participates in numerous physiological processes, including immune-surveillance, oxygen transfer, cellular proliferation and various cellular metabolic activities such as mitochondrial respiration [7]. Whereas unbound iron is highly toxic due to its oxidoreductase function, which may foster the production of reactive oxygen (ROS) and nitrogen species (RNS), a lack of iron is associated with detrimental effects, such as impaired haemoglobin synthesis and mitochondrial dysfunction $[8,9]$. For this reason, human iron homeostasis displays a strictly adjusted transport, recycle and storage system [7] (Fig. 1).

Nutritional heme or non-heme bound iron acquisition takes place in the duodenum where divalent metal transporter 1 (DMT1) or a heme receptor at the luminal and ferroportin 1 (FPN1) at basolateral site act in concert with oxidoreductases (duodenal cytochrome B (DcytB) and hephaestin (HEPH), respectively) to shuttle ionic iron from the enteral lumen to the circulation. Additional, transport systems foster the acquisition of protein bound iron. Hypoxia-inducible factor 2 (HIF2) and ferritin (Ftn) are essential for the regulation of nutritional iron absorption within the gut. In the circulation iron is mainly bound to transferrin (Tf). Tf delivers the metal to target cells, which acquire iron loaded-Tf via receptor mediated endocytosis, involving the transferrin receptor 1 (TfR1). Whereas nutritional iron uptake is relevant for the long term adaption of iron homeostasis, the daily iron need is met via recycling of the metal from senescent red blood cells. The latter is achieved by the mononuclear phagocyte system (MPS). Quantitatively erythropoiesis consumes the major amount of the daily iron turnover, because iron is needed for heme synthesis and permits proliferation of hematopoietic cells. Thus, erythroblasts demonstrate high expression levels of TfR 1 and other iron uptake systems. Hepatic iron storage serves as a buffer system and releases or sequesters iron in chases of higher iron demand or iron overload, respectively. Additional abbreviations: BMP, bone morphogenetic protein; $\mathrm{CP}$, ceruloplasmin; EPO, erythropoietin; ERFE, erythroferrone; $\mathrm{Fe}$, iron; FeTf, iron loaded transferrin; HAMP, hepcidin antimicrobial peptide; Hb, haemoglobin; HFE, human hemochromatosis gene; HGF, hepatocyte growth factor; HMOX 1 , heme oxygenase 1; HP, haptoglobin; Hpx, hemopexin; HRG1, haem transporter 1; IL6, interleukin 6; LIP, labile iron pool; NTBI, non-transferrin bound iron; $\mathrm{O} 2$, oxygen; 
Fig. 1 Regulation of iron homeostasis in the human body

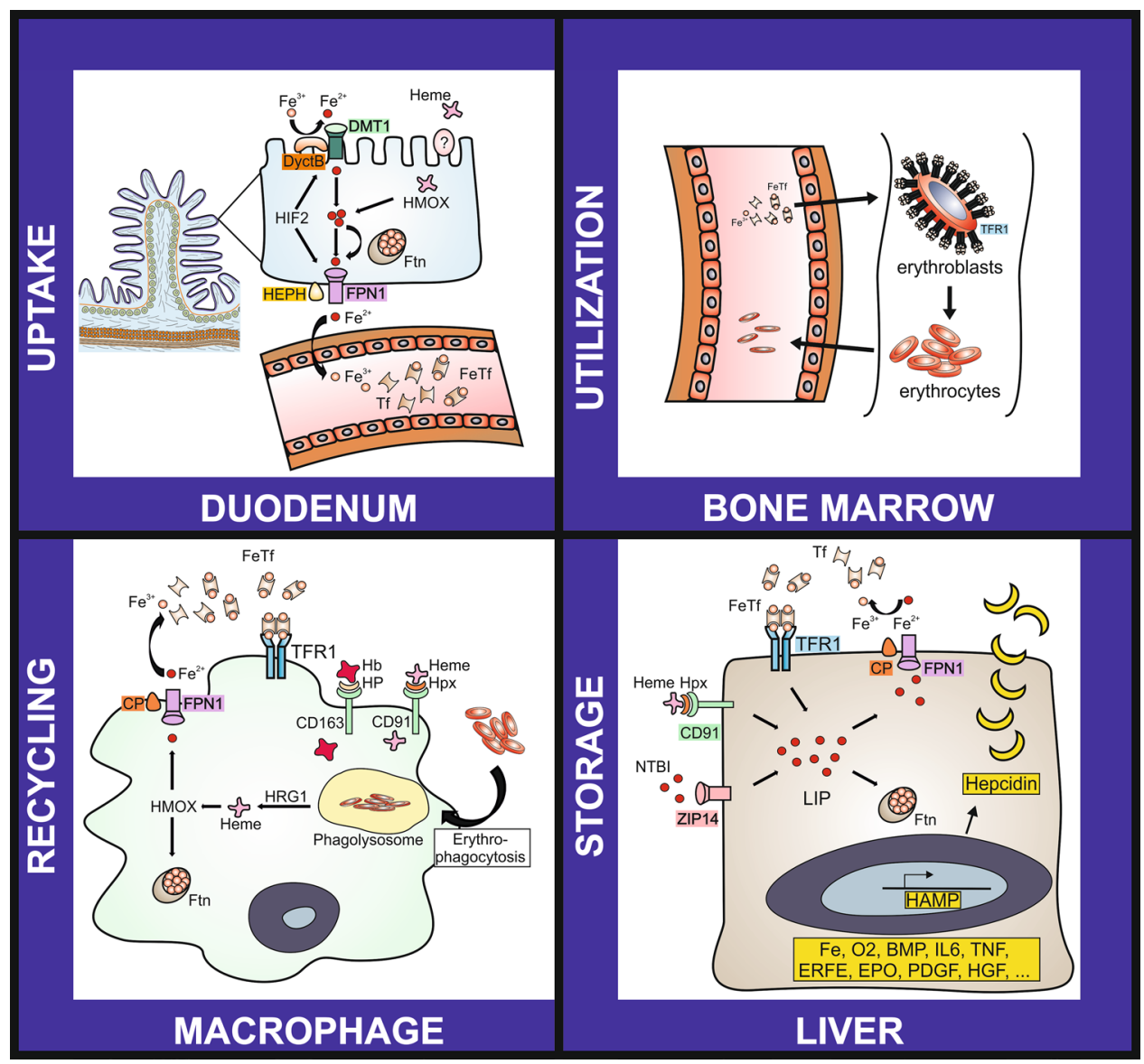

PDGF, platelet-derived growth factor; TNF, tumor necrosis factor; ZIP14, solute carrier family 39 zinc transporter.

In situations of increased iron demand, e.g. acute blood loss or increased haematopoiesis following hypoxic challenge, comprehensive mechanisms adjust iron handling. A central regulator is hepcidin, a small acute phase peptide encoded by the HAMP gene, which controls cellular ferroportin (FPN) expression [10]. FPN is the only known cellular iron exporter, thus hepcidin mediated lysosomal degradation of FPN vastly affects systemic iron availability. A rise in hepcidin results in sequestration of iron within iron storage cells and it constrains duodenal iron acquisition [10]. Consequently, high hepcidin levels reduce systemic iron availability and results in hypoferremia. This mechanism is considered to be a pivotal part of nutritional immunity as it prevents the assimilation of iron by extracellular bacteria, fungi and protozoa, for whom the metal is essential for pathogenicity and proliferation [11]. On the contrary, chronic inflammation in the absence of infection is also associated with an increase of hepcidin and may result in ID [12, 13].

Various alterations of iron metabolism are associated with different pathological features and consequences. Absolute (true) ID, which arises from iron loss (e.g. bleeding), insufficient nutritional iron uptake or malabsorption (mainly found due to under- and/or malnutrition in less developed countries with high poverty rates), or a higher iron demand (e.g. menstruating or pregnant women; children and adolescents), results in an iron-restricted erythropoiesis and may progress into overt IDA [1]. Contrary, the term functional (relative) ID describes a depletion of iron from certain tissues and cells, whereas total body iron content is not reduced [14]. The latter ensues the emergence of ACD. Functional ID is often related to hepcidin overexpression, and due to the previously described inflammation dependent upregulation of hepcidin, it is most frequently found in diseases associated with chronic inflammatory processes $[14,15]$. Whereas absolute ID may be identified rather easily due to markers of depleted iron storage and/or typical features of IDA, such as microcytosis of red blood cells, the diagnosis of functional ID or combined forms of absolute and relative ID may be rather complicated [12]. These complex disorders of iron homeostasis are mainly found due to multifactorial inputs such as chronic inflammation in combination with bleeding episodes, malnutrition and/or malabsorption and may result in complex forms of anaemia (e.g. IDA + ACD or unclassifiable anaemia). 


\section{Pulmonary hypertension}

$\mathrm{PH}$ is a frequent clinical problem, which is found in approximately one per cent of the global population, and its prevalence increases with age, reflected by the estimation that above the age of 65 years approximately $10 \%$ of individuals suffer from PH [16]. The European Society of Cardiology (ESC) and European Respiratory Society (ERS) guidelines define PH by a mean pulmonary arterial pressure (mPAP) of $\geq 25 \mathrm{mmHg}$ at rest measured via right heart catheterization [17]. This currently used hemodynamic definition of $\mathrm{PH}$ has been recently re-evaluated at the 6th World Symposium on Pulmonary Hypertension (WSPH), and may be adapted in future guidelines. Data suggest that the mPAP found in healthy subjects at rest is $14 \pm 3.3 \mathrm{mmHg}$, resulting in a definition of $\mathrm{PH}$ if a mPAP greater than $20 \mathrm{mmHg}$ is present $[18,19]$.

The ESC/ERS categorize PH into five different World Health Organization (WHO) groups or entities [17]. WHO group 1 encompasses patients with idiopathic pulmonary arterial hypertension (IPAH), as well as heritable forms (HPAH), drugs or toxin-induced PH and PH associated with connective tissue disease, portal hypertension, congenital heart disease, human immunodeficiency virus infection or schistosomiasis. Additionally, WHO group 1 includes individuals with pulmonary veno-occlusive disease and/or capillary haemangiomatosis as well as persistent $\mathrm{PH}$ of the newborn. WHO Group 2 covers $\mathrm{PH}$ in patients with left heart disease, and WHO group 3 summarizes individuals with $\mathrm{PH}$ due to lung disease and/or chronic hypoxia. WHO group 4 encompasses patients with $\mathrm{PH}$ caused by thromboembolic events, also termed chronic thromboembolic pulmonary hypertension (CTEPH), or other pulmonary artery obstruction. Finally, WHO group 5 compromises individuals with a $\mathrm{PH}$ of unclear or multifactorial mechanism [17]. Additionally, according to hemodynamic features $\mathrm{PH}$ is subdivided into pre-capillary, post-capillary, and combined pre- and post-capillary $\mathrm{PH}$ (Table 1).

Pre-capillary $\mathrm{PH}$ is mainly found in $\mathrm{PH}$ WHO groups 1,3 , and 4 , whereas post-capillary $\mathrm{PH}$ is a typical feature of WHO group 2 [20]. Combined forms of pre- and post-capillary $\mathrm{PH}$ are present in patients with complex diseases, as seen in WHO group 5, or multi-morbid individuals, e.g. patients with chronic obstructive pulmonary disease (COPD) and heart failure. Quantitatively most cases of $\mathrm{PH}$ demonstrate features of $\mathrm{PH}$ due to left heart disease (WHO group 2) and/or PH due to lung diseases (WHO group 3), whereas a substantially smaller group of patients compromises PAH or CTEPH.

The pathobiology of pre- and post-capillary $\mathrm{PH}$ involves vastly different mechanisms. Pre-capillary PH of WHO group 1 is mainly caused by a chronic progressive remodelling of pulmonary arteries and capillaries, resulting in vessel lumen narrowing and obstruction as well as the formation of complex vessel lesions, also termed plexiform lesions, thrombotic lesions and a partial loss of pre-capillary arteries [20]. This impairment of the pulmonary vascular bed is accompanied by an increase of pulmonary vascular resistance and pulmonary blood pressure as well as a rise of right heart pressure. An acute elevation of right heart pressure, as seen in acute pulmonary embolism, may result in acute right heart failure, whereas chronic pressure elevation induces a dilation and remodelling of the right heart leading to chronically progressive right heart failure. WHO group $4 \mathrm{PH}$ has a distinguished pathobiology as thromboembolic events are the main driver of pulmonary vessel obstruction in this group. Interestingly, even though mechanical obstruction is the main driver of pre-capillary disease in these individuals, vascular remodelling occurs as well, if the mechanical obstruction persists for a longer time [21]. Pre-capillary PH is also frequently found in patients suffering from chronic hypoxia due to pulmonary diseases, such as in individuals with severe COPD [22]. In these patients, mPAP and PVR are typically mild to moderately elevated, whereas patients with IPAH or CTEPH may present with distinctly higher mPAP and pulmonary vascular resistance (PVR).

Post-capillary $\mathrm{PH}$ and mixed pre-post-capillary $\mathrm{PH}$ feature the involvement of post-capillary pulmonary vessels caused by parenchymal destruction, inflammatory processes and chronic elevation of post-capillary pressure as a consequence of impaired left heart function [23]. Additionally, hemolysis and decompartmentalisation of haemoglobin play a pivotal role in the emergence of $\mathrm{PH}$ in WHO group 5 patients suffering from haemoglobinopathies associated
Table 1 Hemodynamic definitions of pulmonary hypertension (adapted from [17])

\begin{tabular}{lllll}
\hline Definition & mPAP $(\mathrm{mmHg})$ & PAWP $(\mathrm{mmHg})$ & PVR $(\mathrm{WU})$ & DPG $(\mathrm{mmHg})$ \\
\hline Pre-capillary PH & $\geq 25$ & $\leq 15$ & $>3$ & $\geq 7$ \\
Post-capillary PH & $\geq 25$ & $>15$ & $\leq 3$ & $<7$ \\
Combined pre- and post- & $\geq 25$ & $>15$ & $>3$ & $\geq 7$ \\
\begin{tabular}{l} 
capillary PH \\
\hline
\end{tabular} & & & \\
\hline
\end{tabular}

$P H$ pulmonary hypertension, $m P A P$ mean pulmonary arterial pressure, $P A W P$ pulmonary arterial wedge pressure, $P V R$ pulmonary vascular resistance, $D P G$ diastolic pressure gradient $(\mathrm{DPG}=$ diastolic PAP (dPAP) - PAWP), $W U$ wood units 
with hemolytic anaemia [24]. In this context it is noteworthy that these diseases are also associated with vast alterations of iron homeostasis. For instance, beta-thalassemia, a hereditary disease associated with hemoglobin deficiency and anaemia, causes massive iron overload which contributes to the development of pulmonary hypertension [25, 26].

The terms pre- and post-capillary PH as well as the term PAH have to be precisely utilized in the clinical practice. PAH specifically defines WHO group 1 pre-capillary pulmonary hypertension and, as depicted previously, post- and combined pre-post-capillary PH are related to different pathomechanisms, thus urge differential treatment approaches. Consequently, PAH specific medications are primarily indicated in PAH and CTEPH, whereas other forms of PH may not benefit from such treatment or even deteriorate after implementation of specific PAH drugs.

Despite these established general concepts of $\mathrm{PH}$ pathobiology and the expansion of knowledge in the field within recent years, many questions concerning the pathobiology of $\mathrm{PH}$ await clarification. An extensive description of the current knowledge of $\mathrm{PH}$ pathology exceeds the scope of this review and the interested reader may be referred to excellent recent reviews on this topic (e.g. [20]). Herein, we focus on the fascinating intersection of iron homeostasis and anaemia with the pathobiology of $\mathrm{PH}$.

\section{Interconnection of pulmonary hypertension, iron homeostasis and anaemia}

Evaluations of PH cohorts demonstrate a high frequency of ID and/or anaemia in $\mathrm{PH}$ patients, as approximately $40-60 \%$ of PH patients demonstrate ID and one-third of all $\mathrm{PH}$ patients suffer from anaemia [27, 28]. Interestingly, both ID and anaemia significantly affect the morbidity and mortality of PH patients [27, 29]. Current evidence suggests a significant role of iron handling in the pathogenesis and clinical outcome of both, pre- and post-capillary pulmonary hypertension [4, 28, 30-32]. First, chronic progressive remodelling of pulmonary vessels, resulting in a loss of pre-capillary pulmonary arteries and a pattern of pulmonary vessels rarefication accompanied by progressive right heart disease is a key feature of PAH and other forms of PH [20]. Vascular remodelling results from complex pathobiology and involves an accumulation of pulmonary artery smooth muscle cells (PASMCs), pulmonary arterial endothelial cells (PAECs), fibroblasts, myofibroblasts and pericytes. Interestingly, the FPN/HAMP axis and the haemoglobin scavenger transporter CD163 are important regulators of cellular function and proliferation of PAECs and PASMCs $[33,34]$. Accordingly, iron dyshomeostasis contributes to pulmonary vascular endothelial dysfunction. Endothelial dysfunction is characterized by an impairment of pulmonary vessel dilation, particularly mediated by overexpression of endothelin 1 (ET1) and suppression of the nitric oxide (NO)/ NO-synthase (NOS) pathway. Of note, iron affects that pathway by reducing the transcriptional expression of inducible NOS, and iron loading of patients has been linked to an impaired end-diastolic dilation along with reduced circulating nitrate levels [35, 36]. Endothelial dysfunction is further linked to NO break down via increased activity of arginase in PAECs [37]. Additionally, perivascular recruitment of B- and T-lymphocytes, macrophages, mast cells, dendritic cells and imbalances of T-regulatory cell function, as well as a T-helper 17 cell immune polarization, are implicated in $\mathrm{PH}$ pathophysiology $[38,39]$. Perivascular inflammation is characterized by a local overexpression of a plethora of chemokines (e.g. macrophage migration inhibitory factor (MIF), cytokines [e.g. interleukin (IL) 1, IL6, IL10 and tumour necrosis factor-alpha (TNFalpha)] and growth factors [e.g. transforming growth factor-beta (TGFbeta) and platelet-derived growth factors (PDGFs)] [20, 38, 39]. Consequently, vasoconstriction, pro-thrombotic activities as well as an impairment of angiogenesis and tissue repair contribute to the distinct pulmonary vascular phenotype in $\mathrm{PH}$ patients $[38,39]$. Interestingly, almost all of these mentioned mechanisms, involved in $\mathrm{PH}$ associated vascular remodeling and endothelial dysfunction, are linked to iron homeostasis, as iron exerts pivotal immunomodulatory effects, including the control of cytokine production and ROS/RNS generation by immune effector cells, the regulation of $\mathrm{T}$ cell polarization, and the functionality of the NO/NOS pathway as well as ET1 expression [8, 11, 34, 40, 41].

Second, heritable forms of PAH are associated with variants in the TGFbeta receptor family and have revealed an important role of bone morphogenetic protein receptor type 2 (BMPR2) mediated signalling in the pathophysiology of PH [42-44]. For instance, treatment with TGFBRII-Fc, a selective TGF-beta1/3 ligand trap, mitigates pulmonary vascular remodelling and $\mathrm{PH}$ in monocrotalinetreated rats, SU5416/hypoxia-treated rats, and SU5416/ hypoxia-treated mice [45]. Additionally, enhancement of BMPR2 function in PAECs reverses the PAH phenotype of mice with heterozygous R899X BMPR2 mutations [44]. Bone morphogenetic proteins (BMPs) interact with various receptors of the TGFbeta receptor family and induce small mothers against decapentaplegic (SMAD) signalling, which facilitates various biological effects including proliferative and immune-modulatory functions [46]. In PAH BMPR2 function also intersects with inflammatory pathways as a reduced BMPR2 activation results in perivascular recruitment of macrophages via the induction of growth factor and granulocyte-macrophage colonystimulating factor (GM-CSF) [47]. Further, the binding of the iron dependent pro-inflammatory cytokine MIF to its receptor CD74 was shown to induce pro-inflammatory 
factors and cell adhesion molecules, such as ICAM1, VCAM1 and E-selectin in PAECs derived from IPAH patients [38]. Thus, MIF/CD74 interaction contributes to vascular inflammation and endothelial dysfunction, two primary instigators of PAH [38]. Noteworthy, BMP/ SMAD signalling is central in the systemic regulation of iron homeostasis, as several BMPs are strong inducers of hepcidin $[7,46]$.

Another link between BMPR2 signalling, perivascular inflammation and iron homeostasis is established for the IL6/ signal transducer and activator of transcription 3 (STAT3) pathway [48]. The expression of IL6, a multifunctional proinflammatory cytokine and anti-inflammatory myokine is induced by iron depletion [49]. Vice versa, IL6 stimulates hepcidin expression via the STAT3 pathway thereby causing intracellular iron sequestration [50]. Notably, PH related BMPR2 deficiency increases intracellular phospho-STAT3 levels in murine and human PASMCs. This process may be escalated via additional stimuli, as chronic lipopolysaccharide (LPS) application triggers PH, and BMPR2 heterozygote mice have a more prominent IL6 and keratinocyte chemoattractant $(\mathrm{KC})$ response to LPS challenge as compared to wildtype littermates [48]. To conclude, a lack of BMPR2 function or expression may promote alterations of iron homeostasis in $\mathrm{PH}$ patients, and iron dyshomeostasis per se alters BMPR2 related singalling, which contribute to the pivotal pathophysiological features of endothelial dysfunction and perivascular inflammation in $\mathrm{PH}$ patients.

Interestingly, the HAMP/FPN axis is also implicated in the emergence of a vasoconstrictive milieu in PAH. Both PASMC and PAECs express FPN, and IL6 and/or hepcidin treatment resulted in FPN suppression and proliferation of PASMCs [33]. In addition, mice with a smooth musclespecific knock-in of the hepcidin-resistant FPN isoform fpnC326Y develop PAH and right heart failure [34]. This process could be linked to an overexpression of FPN, intracellular ID and increased expression of the vasoconstrictor ET1 by PASMCs. Overexpression of ET1 is a key feature in the pathogenesis of PAH. Accordingly, ET1 levels are increased in patients suffering from $\mathrm{PAH}$, and high serum levels of ET1 are associated with an unfavourable clinical outcome [51]. Interestingly, the PAH phenotype of fpnC326Yfl/fl SMMHC-CreERT2 + mice was reversible upon treatment with intravenous iron. Furthermore, intracellular ID in PASMCs contributed to vascular remodelling [34]. Thus, a local dysregulation of iron homeostasis in pulmonary vessels likewise contributes to the emergence of PAH, which, however, is not necessarily associated with systemic alterations of iron homeostasis. Interestingly, a similar mechanism of a locally regulated HAMP/FPN axis was found in cardiomyocytes, which may explain why dysregulation of iron homeostasis is also associated with poor clinical outcome in post-capillary $\mathrm{PH}$ patients with chronic heart disease [52].

Third, acute or chronic hypoxic challenge ensues pulmonary hypertension and results in pulmonary vascular remodelling [53]. The adaption to hypoxic challenge is mainly facilitated by hypoxia-inducible factors (HIFs), which are nuclear transcription factors existing in three different isoforms, namely HIF-1alpha, HIF-2alpha and HIF-3alpha [54]. Hypoxia ensues a HIF mediated increase of erythropoietin (EPO) formation by the kidneys, which induces erythropoiesis and hampers the systemic expression of hepcidin [55]. Hypoxia also induces platelet-derived growth-factor BB (PDGF-BB), erythroferrone (ERFE), matriptase-2 and growth differentiation factor 15 (GDF-15), which mediate hepcidin suppression [7, 56-58]. Consequently, hypoxia increases duodenal iron absorption facilitating a sufficient iron supply for hypoxia triggered stress erythropoiesis [59]. Additionally, HIFs bind to multiple other target genes that are implicated in the expression of growth factors such as vascular endothelial growth factor (VEGF) and TGFbeta which then induce ET1 expression and adapt vessel tension. The expression of HIFs is linked to both, the availability of iron and oxygen. Iron modulates HIF expression via interaction of IRPs with IREs within HIF mRNA [7]. Further, intracellular ID hampers the degradation of HIFs by limiting the activity of iron-dependent prolyl hydroxylases (PHDs) and their interaction with the von Hippel-Lindau (VHL) factor $[59,60]$. Notably, these regulatory mechanisms of iron are essential for the adaption to hypoxic challenge and the emergence of hypoxia triggered PH [53]. Accordingly, ID, application of the iron chelator desferrioxamine (DFO) or iatrogenic blood drain exaggerated hypoxia driven $\mathrm{PH}$. $[53,61]$. These observations in humans are underscored by mechanistic data from rodents showing that IRP1 deletion causes PH in mice through derepression of HIF2alpha [60, 62].

Notably, hypoxia-mediated PH is also linked to proinflammatory processes, and elevated serum levels of proinflammatory cytokines, such as IL1, IL6, MIF, leptin and TNFalpha, are associated with hypoxia, ID and poor prognosis in PH patients [38, 63-66]. In this context, mice with hypoxia-induced $\mathrm{PH}$ display an increased interleukin 1 beta (IL1beta) expression [65]. The interaction of IL1beta with the IL1 receptor (IL1R) mitigates nuclear factor-kappaB (NF-kappaB) activation [65]. NF-kappaB is an iron-dependent transcription factor, which per se induces IL1, IL6 and TNFalpha synthesis. Elevated serum IL6 levels, alterations of STAT3 signalling, ectopic upregulation of the IL6R in PASMCs and IL6 promoted perivascular infiltration of macrophages were all associated with the development of $\mathrm{PH}$ $[48,67]$. Accordingly, hypoxia-induced TNFalpha expression is also linked to PH. TNF inhibits BMPR2 expression and promotes cleavage of BMPR2 via the disintegrin and 
metalloproteases ADAM10 and ADAM17 in PASMCs [66]. Consequently, BMP signalling is subverted and BMPs, such as BMP6 and BMP9, primarily activate the ALK2/ACTRIIA signalling axis, which favours PASMC proliferation and vascular remodelling in heritable PAH $[44,66]$. Additionally, TNFalpha increases $\mathrm{NOTCH} 2$ signalling, which blocks BMPR2 expression [66]. Both IL6 and TNFalpha, also induce ROS/RNS production [55]. A contributing role of ROS to the PH pathobiology is suggestive as induction of ROS by dasatinib induces endothelial cell dysfunction and increased susceptibility to pleural effusion in a PH rodent model [68]. Interestingly, production of ROS/RNS is closely linked to iron availability, as enzymatic processes leading to the generation of ROS/RNS, such as the Fenton-Haber-Weiss reaction, are iron-dependent [69]. Additionally, ROS generation and ID are associated with an impairment of mitochondrial function and have been linked to cardiovascular diseases [70]. For instance, reduced mitochondrial superoxide dismutase 2 (SOD2) levels were found in PASMCs of PAH patients and blunted SOD2 function ensues an apoptosis-resistant phenotype of PASMCs, which may foster PASMC accumulation in pulmonary vessels of $\mathrm{PH}$ patients [71]. In line with this, the mitochondrial ironsulfur cluster scaffold Protein NFU1 is linked to heritable forms of PAH, and the autosomal recessive inheritance of the NFU1 mutation G208C causes PAH in approximately $70 \%$ of affected cases [72].

To conclude, hypoxic stress, alterations of mitochondrial function, ROS/RNS production, blunted NO/NOS signalling, inflammatory processes, BMP/SMAD/HAMP as well as IL6/STAT3/HAMP signalling are all implicated in both, iron handling and the emergence of PH (Fig. 2). Despite these numerous mechanistic links between iron homeostasis and pulmonary hypertension, and a well-established association between ID with/or without anaemia and poor outcome of PH patients, it is currently not clear, if ID and anaemia are merely a consequence of $\mathrm{PH}$ and relate to $\mathrm{PH}$ disease severity, or if they are implicated in the emergence and progression of $\mathrm{PH}$ as causative factors. Notably, different forms of iron dyshomeostasis and anaemia arise in patients suffering from PH [27]. The latter include IDA, ACD and complex forms of anaemia such as a combination of IDA/ACD. These forms of anaemia offer a diagnostic and therapeutic challenge for the clinician, as a precise classification of anaemia may be complicated and straightforward treatment suggestions are not available for complex forms of ID and/or anaemia thus far.

\section{Diagnosis and treatment of iron deficiency and anaemia in patients with pulmonary hypertension}

Based on the accumulating evidence that ID and/or anaemia are frequently associated with $\mathrm{PH}$, and that they affect mortality and morbidity of both, pre- and post-capillary PH patients, the impact of ID and/or anaemia correction on the course of $\mathrm{PH}$ was investigated [4, 5, 73]. However, most evidence originates from iron supplementation trials in patients with congestive heart failure (CHF), who frequently display post-capillary $\mathrm{PH}$. Intravenous iron supplementation in CHF patients with ID improved functional capacity, quality of life and daily symptom burden [4]. Interestingly, anaemia was not a prerequisite for positive treatment response in that study, as both anaemic and non-anaemic CHF patients had a similar amelioration of symptoms following iron replacement. This suggests that ID in the absence of anaemia contributes to reduced
Fig. 2 Current concepts of the interconnection of iron homeostasis, anaemia and pulmonary hypertension. HIF hypoxiainducible factor, $\mathrm{NO}$ nitric oxide, ET1 endothelin 1, $P H$ pulmonary hypertension, $R O S$ reactive oxygen species, $R N S$ reactive nitrogen species, $B M P$ bone morphogenetic protein, $S M A D$ small mothers against decapentaplegic

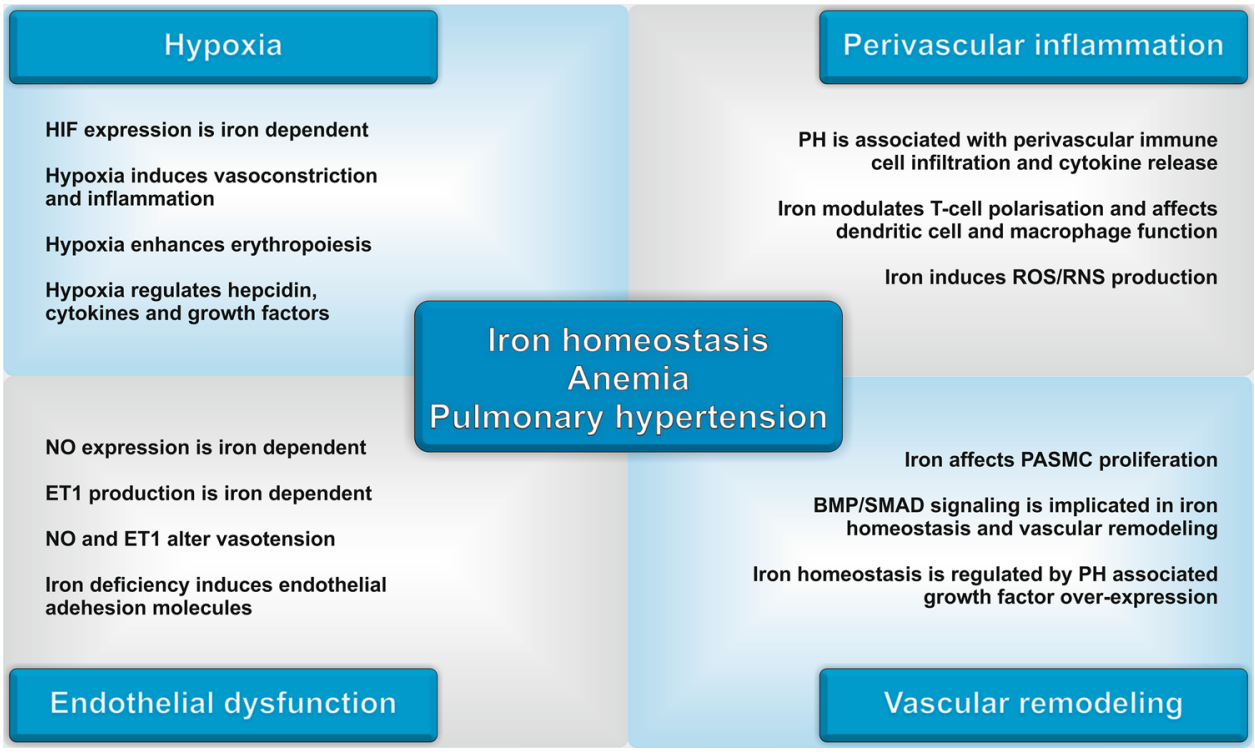


exercise capacity in CHF. Iron supplementation attenuated the normal pulmonary vasoconstrictive response to hypoxia and improved some functional measures in $\mathrm{PH}$ patients regardless of the presence or absence of anaemia $[5,53,61,73,74]$. Thus, iron effects are rather based on alterations of cellular metabolism, mitochondrial function, muscle homeostasis or immune signalling. In pre-capillary PH iron supplementation has been tested in small patient cohorts with IPAH $[5,73]$. Therapeutic correction of ID resulted in improvement of exercise endurance time, aerobic capacity and quality of life $[5,73]$. These observations raise the question if a liberal iron supplementation strategy in PH patients with ID is of general benefit. In this context, it has to be mentioned that both, unbiased oral and intravenous iron administration, harbour limitations and risks in these patients. First, the exact pathophysiology of $\mathrm{PH}$ and PAH, especially the contribution of iron dyshomeostasis, is only partly understood and the consequences of therapeutic modifications of iron homeostasis in these individuals are largely elusive. Secondly, the diagnosis of the specific mode of ID, either absolute or functional or a combination of both is limited by diagnostic uncertainties and lack of good biomarkers specifically in the setting of chronic inflammation [12, 75, 76].

To date, clinical testing for ID mainly relies on the measurement of TSAT and serum ferritin concentration, which results in an inaccurate definition of ID and classification of anaemia in both, the clinical practice and currently available studies [4, 27]. TSAT and serum ferritin are not only altered by iron availability, but also various other triggers, including inflammatory processes and infection. For instance, a ferritin level between $30-100 \mu \mathrm{g} / \mathrm{L}$ may be indicative of appropriate iron availability in patients without signs of inflammation, whereas in patients with ongoing inflammatory processes the same value may be associated with functional ID [12, 77]. In this context, the measurement of sTFR, the sTFR/log ferritin index (sTFRF) and serum hepcidin may foster a more precise characterization of specific types of ID. Still, cut-offs and used parameters to best define ID in PH patients in the clinical practice are still controversial, which is reflected by a highly heterogenous definition of ID in various clinical trials (Table 2). A detailed evaluation of this topic was recently published by our working group [27].

The issue of differentiating absolute from functional ID is from great clinical relevance because different therapy strategies would be applicable [1]. While iron supplementation is likely to be beneficial in situations of absolute ID, adding surplus iron to patients with inflammation-driven functional iron retention may be ineffective or even detrimental in certain conditions. Adverse effects of iron supplementation may include an impairment of the immune-surveillance or feeding of circulating pathogens leading to aggravation of infectious diseases, a hypothetic but not well-studied effect on malignant cell proliferation or the emergence of toxic iron effects via increased ROS/RNS production leading to cellular damage [11]. Consequently, available data on iron supplementation in $\mathrm{PH}$ patients have to be interpreted with caution and current evidence urges further investigation prior to the implementation of liberal iron supplementation strategies in PH patients. Third, and most importantly, we need to specifically identify those patients who will benefit from iron supplementation along with the definition of therapeutic start and endpoints.

Similarly to ID, anaemia has a high prevalence and is associated with increased disease severity and poor clinical outcome in $\mathrm{PH}$ patients [27, 28, 32]. The pathobiology of anaemia in $\mathrm{PH}$ is complex as various triggers including hypoxia, chronic blood loss, renal dysfunction, malnutrition, ID, chronic inflammation or recurrent infections are frequently found in $\mathrm{PH}$. Consequently, $\mathrm{PH}$ patients represent various forms of anaemia, including ACD, IDA, IDA + ACD and non-classifiable/multifactorial forms of anaemia and the categorization and treatment of anaemia is complicated in these individuals [27]. To address this issue, additional parameters have been suggested to evaluate iron homeostasis in patients with PH. First, serum hepcidin measurements may help to predict response to oral iron treatment $[13,78]$. Secondly, serum quantification of soluble transferrin receptor (sTFR) reflects cellular iron demand in the bone marrow $[5,27,79]$. The
Table 2 Most commonly used definitions of iron deficiency in patients with pulmonary hypertension

\begin{tabular}{lllll}
\hline ID definitions & Serum ferritin $(\mu \mathrm{g} / \mathrm{L})$ & TSAT $(\%)$ & sTFR $(\mathrm{mg} / \mathrm{L})$ & sTFRF index \\
\hline ID 1 & $<30$ & $<16$ & - & - \\
ID 2 & $<100$ & $<20$ & - & - \\
ID 3 & $<100$ & & - & - \\
& or 100-299 & If $<20$ & & - \\
ID 4 & - & - & $>4.5($ female $)$ & - \\
& & - & $>5.0($ male $)$ & $>3.2 \mathrm{if} \mathrm{CRP}<0.5 \mathrm{mg} / \mathrm{dL}$ \\
ID 5 & - & & & $>2.0 \mathrm{if} \mathrm{CRP}>0.5 \mathrm{mg} / \mathrm{dL}$ \\
\hline
\end{tabular}

$I D$ iron deficiency, TSAT transferrin saturation, CRP C-reactive protein, $S T F R$ soluble transferrin receptor, sTFRF index soluble transferrin receptor/log serum ferritin index; for a detailed evaluation of this topic refer to [27] 
Table 3 Classification of anaemia in pulmonary hypertension (adapted from [3])

\begin{tabular}{lllll}
\hline & IDA & ACD & IDA+ACD & Unclassified anaemia \\
\hline Haemoglobin & $<120 \mathrm{~g} / \mathrm{L}$ for woman $<130 \mathrm{~g} / \mathrm{L}$ for men & & $>30 \mu \mathrm{g} / \mathrm{L}$ \\
Serum ferritin & $<30 \mu \mathrm{g} / \mathrm{L}$ & $>100 \mu \mathrm{g} / \mathrm{L}$ or $30-100 \mu \mathrm{g} / \mathrm{L}$ with & $30-100 \mu \mathrm{g} / \mathrm{L}$ & Variable \\
& & reduced sTFRF index & $<2$ & $1-2$ \\
TSAT & $<20 \%$ & $<20 \%$ & $>2$ & Variable \\
sTFRF index & $>2$ & $<1$ if serum ferritin $30-100 \mu \mathrm{g} / \mathrm{L}$ & Normal or decreased & \\
Serum hepcidin & $\begin{array}{l}\text { Reduced to below } \\
\text { detection limit }\end{array}$ & Increased above normal & & \\
\hline
\end{tabular}

IDA iron deficiency anaemia, $A C D$ anaemia of chronic disease, IDA $+A C D$ a combination of IDA and ACD, sTFRF index soluble transferrin receptor log ferritin index, TSAT transferrin saturation

combination of sTFR and serum ferritin measurement permits the calculation of the sTFR/logferritin (sTFRF) index, which is currently considered as a clinical robust parameter to characterize iron homeostasis and anaemia, as it takes cellular iron demand and iron storage into account and may be corrected according to systemic signs of inflammation [12, 27]. Additionally, red cell indices as well as red cell distribution width (RDW) and zincprotoporphyrin (Zn-pp) levels may help to identify functional ID at an earlier stage and may foster a diagnosis of functional ID prior to the emergence of anaemia or support the diagnosis of ACD [77, 78, 80]. Table 3 proposes a potential concept for clinicians to specify anaemia in $\mathrm{PH}$ patients.

\section{Conclusion and perspective}

Accumulating evidence suggests a pivotal role of iron homeostasis and anaemia in the pathophysiology, progression and prognosis of $\mathrm{PH}$. Across all entities of $\mathrm{PH}$, disturbances of iron homeostasis and anaemia are frequently observed, thus may represent a relevant contributor to disease severity and act as a potential treatment target in these patients. Still, due to the lack of clinically useful biomarkers, which precisely distinguish functional and true ID, and the lack of proper powered prospective randomized interventional trials in all different $\mathrm{PH}$ categories, iron supplementation has to be indicated with caution in $\mathrm{PH}$ patients. Systemic or local inflammation alters iron handling and puts patients at risk to suffer from potential detrimental effects of iron treatment. On the contrary, iron substitution may be safe and efficient in patients with true ID or IDA and it is important to screen for those conditions, as their treatment significantly improves PH patients' morbidity and mortality. Consequently, the understanding of the interconnection of iron homeostasis, anaemia and pulmonary hypertension is a matter of high relevance, and ongoing scientific progress in the field offers the opportunity to close current knowledge gaps and provide new treatment options for $\mathrm{PH}$ patients.

\section{Methodology}

We collected data and references with PubMed, MEDLINE, Google, and Google Scholar. The following keywords were used for literature search: anaemia, iron homeostasis, iron deficiency anaemia, anaemia of chronic disease, pulmonary hypertension, hypoxia.

Acknowledgements Open access funding provided by University of Innsbruck and Medical University of Innsbruck.

Author contributions TS, AP, IT, JLR and GW performed literature research. TS prepared the figure and tables. TS, JLR, IT, AP and GW wrote the paper. GW and JLR acquired funding.

Funding This work was supported by the Austrian National bank Fund (Project 17271, J.LR.), by the "Verein zur Förderung von Forschung und Weiterbildung in Infektiologie und Immunologie", Innsbruck, Austria (G.W.) and the Christian Doppler Society, Austria (G.W.).

\section{Compliance with ethical standards}

Conflict of interest GW received financial payment for advisory board participation (Vifor Pharma), all other authors declare no conflict of interest connected with this study.

Statement of human and animal rights The study was performed in accordance with the guidelines of the local ethics committee and the declaration of Helsinki.

Ethical approval Ethical approval was given by the local ethics committee.

Informed consent For this retrospective review, formal consent is not required.

Open Access This article is licensed under a Creative Commons Attribution 4.0 International License, which permits use, sharing, adaptation, distribution and reproduction in any medium or format, as long as you give appropriate credit to the original author(s) and the source, provide a link to the Creative Commons licence, and indicate if changes 
were made. The images or other third party material in this article are included in the article's Creative Commons licence, unless indicated otherwise in a credit line to the material. If material is not included in the article's Creative Commons licence and your intended use is not permitted by statutory regulation or exceeds the permitted use, you will need to obtain permission directly from the copyright holder. To view a copy of this licence, visit http://creativecommons.org/licenses/by/4.0/.

\section{References}

1. Camaschella C (2017) New insights into iron deficiency and iron deficiency anemia. Blood Rev 31(4):225-233. https://doi. org/10.1016/j.blre.2017.02.004

2. Kassebaum NJ, Jasrasaria R, Naghavi M, Wulf SK, Johns N, Lozano R, Regan M, Weatherall D, Chou DP, Eisele TP, Flaxman SR, Pullan RL, Brooker SJ, Murray CJ (2014) A systematic analysis of global anemia burden from 1990 to 2010. Blood 123(5):615-624. https://doi.org/10.1182/blood-2013-06-508325

3. Weiss G, Goodnough LT (2005) Anemia of chronic disease. N Engl J Med 352(10):1011-1023. https://doi.org/10.1056/NEJMr a041809

4. Anker SD, Comin Colet J, Filippatos G, Willenheimer R, Dickstein K, Drexler H, Luscher TF, Bart B, Banasiak W, Niegowska J, Kirwan BA, Mori C, von Eisenhart Rothe B, Pocock SJ, Poole-Wilson PA, Ponikowski P, Investigators F-HT (2009) Ferric carboxymaltose in patients with heart failure and iron deficiency. N Engl J Med 361(25):2436-2448. https://doi. org/10.1056/NEJMoa0908355

5. Ruiter G, Manders E, Happe CM, Schalij I, Groepenhoff H, Howard LS, Wilkins MR, Bogaard HJ, Westerhof N, van der Laarse WJ, de Man FS, Vonk-Noordegraaf A (2015) Intravenous iron therapy in patients with idiopathic pulmonary arterial hypertension and iron deficiency. Pulmon Circ 5(3):466-472. https://doi.org/10.1086/682217

6. van Veldhuisen DJ, Ponikowski P, van der Meer P, Metra M, Bohm M, Doletsky A, Voors AA, Macdougall IC, Anker SD, Roubert B, Zakin L, Cohen-Solal A, Investigators E-H (2017) Effect of ferric carboxymaltose on exercise capacity in patients with chronic heart failure and iron deficiency. Circulation 136(15):1374-1383. https://doi.org/10.1161/CIRCULATIO NAHA.117.027497

7. Muckenthaler MU, Rivella S, Hentze MW, Galy B (2017) A red carpet for iron metabolism. Cell 168(3):344-361. https://doi. org/10.1016/j.cell.2016.12.034

8. Oexle H, Gnaiger E, Weiss G (1999) Iron-dependent changes in cellular energy metabolism: influence on citric acid cycle and oxidative phosphorylation. Biochem Biophys Acta 1413(3):99-107

9. Volani C, Doerrier C, Demetz E, Haschka D, Paglia G, Lavdas AA, Gnaiger E, Weiss G (2017) Dietary iron loading negatively affects liver mitochondrial function. Metallomics 9(11):1634 1644. https://doi.org/10.1039/c7mt00177k

10. Nemeth E, Tuttle MS, Powelson J, Vaughn MB, Donovan A, Ward DM, Ganz T, Kaplan J (2004) Hepcidin regulates cellular iron efflux by binding to ferroportin and inducing its internalization. Science 306(5704):2090-2093. https://doi.org/10.1126/scien ce. 1104742

11. Soares MP, Weiss G (2015) The iron age of host-microbe interactions. EMBO Rep 16(11):1482-1500. https://doi.org/10.15252/ embr.201540558

12. Weiss G (2015) Anemia of chronic disorders: new diagnostic tools and new treatment strategies. Semin Hematol 52(4):313-320. https://doi.org/10.1053/j.seminhematol.2015.07.004
13. Girelli D, Nemeth E, Swinkels DW (2016) Hepcidin in the diagnosis of iron disorders. Blood 127(23):2809-2813. https://doi. org/10.1182/blood-2015-12-639112

14. Weiss G, Ganz T, Goodnough LT (2019) Anemia of inflammation. Blood 133(1):40-50. https://doi.org/10.1182/blood-2018-06856500

15. Theurl I, Schroll A, Nairz M, Seifert M, Theurl M, Sonnweber T, Kulaksiz H, Weiss G (2011) Pathways for the regulation of hepcidin expression in anemia of chronic disease and iron deficiency anemia in vivo. Haematologica 96(12):1761-1769. https://doi. org/10.3324/haematol.2011.048926

16. Hoeper MM, Humbert M, Souza R, Idrees M, Kawut SM, SliwaHahnle K, Jing ZC, Gibbs JS (2016) A global view of pulmonary hypertension. Lancet Respir Med 4(4):306-322. https://doi. org/10.1016/S2213-2600(15)00543-3

17. Galie N, Humbert M, Vachiery JL, Gibbs S, Lang I, Torbicki A, Simonneau G, Peacock A, Vonk Noordegraaf A, Beghetti M, Ghofrani A, Gomez Sanchez MA, Hansmann G, Klepetko W, Lancellotti P, Matucci M, McDonagh T, Pierard LA, Trindade PT, Zompatori M, Hoeper M (2016) 2015 ESC/ERS guidelines for the diagnosis and treatment of pulmonary hypertension. Rev Esp Cardiol (Engl Ed) 69(2):177. https://doi.org/10.1016/j. rec.2016.01.002

18. Kovacs G, Berghold A, Scheidl S, Olschewski H (2009) Pulmonary arterial pressure during rest and exercise in healthy subjects: a systematic review. Eur Respir J 34(4):888-894. https://doi. org/10.1183/09031936.00145608

19. Simonneau G, Montani D, Celermajer DS, Denton CP, Gatzoulis MA, Krowka M, Williams PG, Souza R (2019) Haemodynamic definitions and updated clinical classification of pulmonary hypertension. Eur Respir J. https://doi.org/10.1183/13993003.01913 $-2018$

20. Humbert M, Guignabert C, Bonnet S, Dorfmuller P, Klinger JR, Nicolls MR, Olschewski AJ, Pullamsetti SS, Schermuly RT, Stenmark KR, Rabinovitch M (2019) Pathology and pathobiology of pulmonary hypertension: state of the art and research perspectives. Eur Respir J. https://doi.org/10.1183/13993003.01887-2018

21. Dorfmuller P, Gunther S, Ghigna MR, Thomas de Montpreville V, Boulate D, Paul JF, Jais X, Decante B, Simonneau G, Dartevelle P, Humbert M, Fadel E, Mercier O (2014) Microvascular disease in chronic thromboembolic pulmonary hypertension: a role for pulmonary veins and systemic vasculature. Eur Respir J 44(5):1275-1288. https://doi.org/10.1183/09031936.00169113

22. Plesner LL, Schoos MM, Dalsgaard M, Goetze JP, Kjoller E, Vestbo J, Iversen K (2017) Iron deficiency in COPD associates with increased pulmonary artery pressure estimated by echocardiography. Heart Lung Circ 26(1):101-104. https://doi. org/10.1016/j.hlc.2016.04.020

23. Fayyaz AU, Edwards WD, Maleszewski JJ, Konik EA, DuBrock HM, Borlaug BA, Frantz RP, Jenkins SM, Redfield MM (2018) Global pulmonary vascular remodeling in pulmonary hypertension associated with heart failure and preserved or reduced ejection fraction. Circulation 137(17):1796-1810. https://doi. org/10.1161/CIRCULATIONAHA.117.031608

24. Barnett CF, Hsue PY, Machado RF (2008) Pulmonary hypertension: an increasingly recognized complication of hereditary hemolytic anemias and HIV infection. JAMA 299(3):324-331. https:// doi.org/10.1001/jama.299.3.324

25. Darton TC, Blohmke CJ, Giannoulatou E, Waddington CS, Jones C, Sturges P, Webster C, Drakesmith H, Pollard AJ, Armitage AE (2015) Rapidly escalating hepcidin and associated serum iron starvation are features of the acute response to typhoid infection in humans. PLoS Negl Trop Dis 9(9):e0004029. https://doi. org/10.1371/journal.pntd.0004029

26. Derchi G, Galanello R, Bina P, Cappellini MD, Piga A, Lai ME, Quarta A, Casu G, Perrotta S, Pinto V, Musallam KM, Forni GL 
(2014) Prevalence and risk factors for pulmonary arterial hypertension in a large group of beta-thalassemia patients using right heart catheterization: a Webthal study. Circulation 129(3):338345. https://doi.org/10.1161/CIRCULATIONAHA.113.002124

27. Sonnweber T, Nairz M, Theurl I, Petzer V, Tymoszuk P, Haschka D, Rieger E, Kaessmann B, Deri M, Watzinger K, SteringerMascherbauer R, Tancevski I, Weiss G, Loffler-Ragg J (2018) The crucial impact of iron deficiency definition for the course of precapillary pulmonary hypertension. PLoS One 13(8):e0203396. https://doi.org/10.1371/journal.pone.0203396

28. Rhodes CJ, Howard LS, Busbridge M, Ashby D, Kondili E, Gibbs JS, Wharton J, Wilkins MR (2011) Iron deficiency and raised hepcidin in idiopathic pulmonary arterial hypertension: clinical prevalence, outcomes, and mechanistic insights. J Am Coll Cardiol 58(3):300-309. https://doi.org/10.1016/j.jacc.2011.02.057

29. Rhodes CJ, Wharton J, Ghataorhe P, Watson G, Girerd B, Howard LS, Gibbs JSR, Condliffe R, Elliot CA, Kiely DG, Simonneau G, Montani D, Sitbon O, Gall H, Schermuly RT, Ghofrani HA, Lawrie A, Humbert M, Wilkins MR (2017) Plasma proteome analysis in patients with pulmonary arterial hypertension: an observational cohort study. Lancet Respir Med 5(9):717-726. https://doi. org/10.1016/S2213-2600(17)30161-3

30. Ruiter G, Lankhorst S, Boonstra A, Postmus PE, Zweegman S, Westerhof N, van der Laarse WJ, Vonk-Noordegraaf A (2011) Iron deficiency is common in idiopathic pulmonary arterial hypertension. Eur Respir J 37(6):1386-1391. https://doi. org/10.1183/09031936.00100510

31. Soon E, Treacy CM, Toshner MR, MacKenzie-Ross R, Manglam V, Busbridge M, Sinclair-McGarvie M, Arnold J, Sheares KK, Morrell NW, Pepke-Zaba J (2011) Unexplained iron deficiency in idiopathic and heritable pulmonary arterial hypertension. Thorax 66(4):326-332. https://doi.org/10.1136/thx.2010.147272

32. van Empel VP, Lee J, Williams TJ, Kaye DM (2014) Iron deficiency in patients with idiopathic pulmonary arterial hypertension. Heart Lung Circ 23(3):287-292. https://doi.org/10.1016/j. hlc.2013.08.007

33. Ramakrishnan L, Pedersen SL, Toe QK, West LE, Mumby S, Casbolt H, Issitt T, Garfield B, Lawrie A, Wort SJ, Quinlan GJ (2018) The hepcidin/ferroportin axis modulates proliferation of pulmonary artery smooth muscle cells. Sci Rep 8(1):12972. https ://doi.org/10.1038/s41598-018-31095-0

34. Lakhal-Littleton S, Crosby A, Frise MC, Mohammad G, Carr CA, Loick PAM, Robbins PA (2019) Intracellular iron deficiency in pulmonary arterial smooth muscle cells induces pulmonary arterial hypertension in mice. Proc Natl Acad Sci USA 116(26):13122-13130. https://doi.org/10.1073/pnas.1822010116

35. Weiss G, Werner-Felmayer G, Werner ER, Grunewald K, Wachter H, Hentze MW (1994) Iron regulates nitric oxide synthase activity by controlling nuclear transcription. J Exp Med 180(3):969-976

36. Gaenzer H, Marschang P, Sturm W, Neumayr G, Vogel W, Patsch J, Weiss G (2002) Association between increased iron stores and impaired endothelial function in patients with hereditary hemochromatosis. J Am Coll Cardiol 40(12):2189-2194. https://doi. org/10.1016/s0735-1097(02)02611-6

37. Xu W, Kaneko FT, Zheng S, Comhair SA, Janocha AJ, Goggans T, Thunnissen FB, Farver C, Hazen SL, Jennings C, Dweik RA, Arroliga AC, Erzurum SC (2004) Increased arginase II and decreased NO synthesis in endothelial cells of patients with pulmonary arterial hypertension. FASEB J 18(14):1746-1748. https ://doi.org/10.1096/fj.04-2317fje

38. Le Hiress M, Tu L, Ricard N, Phan C, Thuillet R, Fadel E, Dorfmuller P, Montani D, de Man F, Humbert M, Huertas A, Guignabert C (2015) Proinflammatory signature of the dysfunctional endothelium in pulmonary hypertension. Role of the macrophage migration inhibitory factor/CD74 complex. Am J
Respir Crit Care Med 192(8):983-997. https://doi.org/10.1164/ rccm.201402-0322oc

39. Huertas A, Perros F, Tu L, Cohen-Kaminsky S, Montani D, Dorfmuller P, Guignabert C, Humbert M (2014) Immune dysregulation and endothelial dysfunction in pulmonary arterial hypertension: a complex interplay. Circulation 129(12):1332-1340. https ://doi.org/10.1161/CIRCULATIONAHA.113.004555

40. Sonnweber T, Theurl I, Seifert M, Schroll A, Eder S, Mayer G, Weiss G (2011) Impact of iron treatment on immune effector function and cellular iron status of circulating monocytes in dialysis patients. Nephrol Dial Transplant 26(3):977-987. https://doi. org/10.1093/ndt/gfq483

41. Weiss G, Goossen B, Doppler W, Fuchs D, Pantopoulos K, Werner-Felmayer G, Wachter H, Hentze MW (1993) Translational regulation via iron-responsive elements by the nitric oxide/NOsynthase pathway. EMBO J 12(9):3651-3657

42. Chew JD, Loyd JE, Austin ED (2017) Genetics of pulmonary arterial hypertension. Semin Respir Crit Care Med 38(5):585-595. https://doi.org/10.1055/s-0037-1606201

43. Tojais NF, Cao A, Lai YJ, Wang L, Chen PI, Alcazar MAA, de Jesus Perez VA, Hopper RK, Rhodes CJ, Bill MA, Sakai LY, Rabinovitch M (2017) Codependence of bone morphogenetic protein receptor 2 and transforming growth factor-beta in elastic fiber assembly and its perturbation in pulmonary arterial hypertension. Arterioscler Thromb Vasc Biol 37(8):1559-1569. https ://doi.org/10.1161/ATVBAHA.117.309696

44. Long L, Ormiston ML, Yang X, Southwood M, Graf S, Machado RD, Mueller M, Kinzel B, Yung LM, Wilkinson JM, Moore SD, Drake KM, Aldred MA, Yu PB, Upton PD, Morrell NW (2015) Selective enhancement of endothelial BMPR-II with BMP9 reverses pulmonary arterial hypertension. Nat Med 21(7):777785. https://doi.org/10.1038/nm.3877

45. Yung LM, Nikolic I, Paskin-Flerlage SD, Pearsall RS, Kumar R, Yu PB (2016) A selective transforming growth factor-beta ligand trap attenuates pulmonary hypertension. Am J Respir Crit Care Med 194(9):1140-1151. https://doi.org/10.1164/rccm.20151 $0-19550 C$

46. Kautz L, Meynard D, Monnier A, Darnaud V, Bouvet R, Wang RH, Deng C, Vaulont S, Mosser J, Coppin H, Roth MP (2008) Iron regulates phosphorylation of $\mathrm{Smad} 1 / 5 / 8$ and gene expression of Bmp6, Smad 7, Id1, and Atoh8 in the mouse liver. Blood 112(4):1503-1509. https://doi.org/10.1182/blood-2008-03-14335 4

47. Sawada H, Saito T, Nickel NP, Alastalo TP, Glotzbach JP, Chan R, Haghighat L, Fuchs G, Januszyk M, Cao A, Lai YJ, Perez Vde J, Kim YM, Wang L, Chen PI, Spiekerkoetter E, Mitani Y, Gurtner GC, Sarnow P, Rabinovitch M (2014) Reduced BMPR2 expression induces GM-CSF translation and macrophage recruitment in humans and mice to exacerbate pulmonary hypertension. J Exp Med 211(2):263-280. https://doi.org/10.1084/jem.20111741

48. Hashimoto-Kataoka T, Hosen N, Sonobe T, Arita Y, Yasui T, Masaki T, Minami M, Inagaki T, Miyagawa S, Sawa Y, Murakami M, Kumanogoh A, Yamauchi-Takihara K, Okumura M, Kishimoto T, Komuro I, Shirai M, Sakata Y, Nakaoka Y (2015) Interleukin-6/interleukin-21 signaling axis is critical in the pathogenesis of pulmonary arterial hypertension. Proc Natl Acad Sci USA 112(20):E2677-E2686. https://doi.org/10.1073/pnas.1424774112

49. Nairz M, Theurl I, Swirski FK, Weiss G (2017) "Pumping iron"how macrophages handle iron at the systemic, microenvironmental, and cellular levels. Pflugers Arch 469(3-4):397-418. https:// doi.org/10.1007/s00424-017-1944-8

50. Nemeth E, Rivera S, Gabayan V, Keller C, Taudorf S, Pedersen BK, Ganz T (2004) IL-6 mediates hypoferremia of inflammation by inducing the synthesis of the iron regulatory hormone hepcidin. 
J Clin Investig 113(9):1271-1276. https://doi.org/10.1172/JCI20 945

51. Giaid A, Yanagisawa M, Langleben D, Michel RP, Levy R, Shennib H, Kimura S, Masaki T, Duguid WP, Stewart DJ (1993) Expression of endothelin-1 in the lungs of patients with pulmonary hypertension. N Engl J Med 328(24):1732-1739. https://doi. org/10.1056/NEJM199306173282402

52. Lakhal-Littleton S, Wolna M, Chung YJ, Christian HC, Heather LC, Brescia M, Ball V, Diaz R, Santos A, Biggs D, Clarke K, Davies B, Robbins PA (2016) An essential cell-autonomous role for hepcidin in cardiac iron homeostasis. Elife. https://doi. org/10.7554/eLife.19804

53. Smith TG, Balanos GM, Croft QP, Talbot NP, Dorrington KL, Ratcliffe PJ, Robbins PA (2008) The increase in pulmonary arterial pressure caused by hypoxia depends on iron status. J Physiol 586(24):5999-6005. https://doi.org/10.1113/jphysiol.2008.16096 0

54. Bishop T, Ratcliffe PJ (2015) HIF hydroxylase pathways in cardiovascular physiology and medicine. Circ Res 117(1):65-79. https ://doi.org/10.1161/CIRCRESAHA.117.305109

55. Nicolas G, Chauvet C, Viatte L, Danan JL, Bigard X, Devaux I, Beaumont C, Kahn A, Vaulont S (2002) The gene encoding the iron regulatory peptide hepcidin is regulated by anemia, hypoxia, and inflammation. J Clin Investig 110(7):1037-1044. https://doi. org/10.1172/JCI15686

56. Kautz L, Jung G, Valore EV, Rivella S, Nemeth E, Ganz T (2014) Identification of erythroferrone as an erythroid regulator of iron metabolism. Nat Genet 46(7):678-684. https://doi.org/10.1038/ ng.2996

57. Liu Q, Davidoff O, Niss K, Haase VH (2012) Hypoxia-inducible factor regulates hepcidin via erythropoietin-induced erythropoiesis. J Clin Investig 122(12):4635-4644. https://doi.org/10.1172/ JCI63924

58. Sonnweber T, Nachbaur D, Schroll A, Nairz M, Seifert M, Demetz E, Haschka D, Mitterstiller AM, Kleinsasser A, Burtscher M, Trubsbach S, Murphy AT, Wroblewski V, Witcher DR, MleczkoSanecka K, Vecchi C, Muckenthaler MU, Pietrangelo A, Theurl I, Weiss G (2014) Hypoxia induced downregulation of hepcidin is mediated by platelet derived growth factor BB. Gut 63(12):19511959. https://doi.org/10.1136/gutjnl-2013-305317

59. Peyssonnaux C, Zinkernagel AS, Schuepbach RA, Rankin E, Vaulont S, Haase VH, Nizet V, Johnson RS (2007) Regulation of iron homeostasis by the hypoxia-inducible transcription factors (HIFs). J Clin Investig 117(7):1926-1932. https://doi.org/10.1172/JCI31 370

60. Ghosh MC, Zhang DL, Jeong SY, Kovtunovych G, OllivierreWilson H, Noguchi A, Tu T, Senecal T, Robinson G, Crooks DR, Tong WH, Ramaswamy K, Singh A, Graham BB, Tuder RM, Yu ZX, Eckhaus M, Lee J, Springer DA, Rouault TA (2013) Deletion of iron regulatory protein 1 causes polycythemia and pulmonary hypertension in mice through translational derepression of HIF2alpha. Cell Metab 17(2):271-281. https://doi.org/10.1016/j. cmet.2012.12.016

61. Smith TG, Talbot NP, Privat C, Rivera-Ch M, Nickol AH, Ratcliffe PJ, Dorrington KL, Leon-Velarde F, Robbins PA (2009) Effects of iron supplementation and depletion on hypoxic pulmonary hypertension: two randomized controlled trials. JAMA 302(13):1444-1450. https://doi.org/10.1001/jama.2009.1404

62. Dai Z, Li M, Wharton J, Zhu MM, Zhao YY (2016) Prolyl-4 hydroxylase 2 (PHD2) deficiency in endothelial cells and hematopoietic cells induces obliterative vascular remodeling and severe pulmonary arterial hypertension in mice and humans through hypoxia-inducible factor-2alpha. Circulation 133(24):2447-2458. https://doi.org/10.1161/CIRCULATIONAHA.116.021494
63. Eltzschig HK, Carmeliet P (2011) Hypoxia and inflammation. $\mathrm{N}$ Engl J Med 364(7):656-665. https://doi.org/10.1056/NEJMra0910 283

64. Soon E, Holmes AM, Treacy CM, Doughty NJ, Southgate L, Machado RD, Trembath RC, Jennings S, Barker L, Nicklin P, Walker C, Budd DC, Pepke-Zaba J, Morrell NW (2010) Elevated levels of inflammatory cytokines predict survival in idiopathic and familial pulmonary arterial hypertension. Circulation 122(9):920 927. https://doi.org/10.1161/CIRCULATIONAHA.109.933762

65. Parpaleix A, Amsellem V, Houssaini A, Abid S, Breau M, Marcos E, Sawaki D, Delcroix M, Quarck R, Maillard A, Couillin I, Ryffel B, Adnot S (2016) Role of interleukin-1 receptor 1/MyD88 signalling in the development and progression of pulmonary hypertension. Eur Respir J 48(2):470-483. https://doi.org/10.1183/13993 003.01448-2015

66. Hurst LA, Dunmore BJ, Long L, Crosby A, Al-Lamki R, Deighton J, Southwood M, Yang X, Nikolic MZ, Herrera B, Inman GJ, Bradley JR, Rana AA, Upton PD, Morrell NW (2017) TNFalpha drives pulmonary arterial hypertension by suppressing the BMP type-II receptor and altering NOTCH signalling. Nat Commun 8:14079. https://doi.org/10.1038/ncomms14079

67. Tamura Y, Phan C, Tu L, Le Hiress M, Thuillet R, Jutant EM, Fadel E, Savale L, Huertas A, Humbert M, Guignabert C (2018) Ectopic upregulation of membrane-bound IL6R drives vascular remodeling in pulmonary arterial hypertension. J Clin Investig 128(5):1956-1970. https://doi.org/10.1172/JCI96462

68. Guignabert C, Phan C, Seferian A, Huertas A, Tu L, Thuillet R, Sattler C, Le Hiress M, Tamura Y, Jutant EM, Chaumais MC, Bouchet S, Maneglier B, Molimard M, Rousselot P, Sitbon O, Simonneau G, Montani D, Humbert M (2016) Dasatinib induces lung vascular toxicity and predisposes to pulmonary hypertension. J Clin Investig 126(9):3207-3218. https://doi.org/10.1172/JCI86 249

69. Koskenkorva-Frank TS, Weiss G, Koppenol WH, Burckhardt S (2013) The complex interplay of iron metabolism, reactive oxygen species, and reactive nitrogen species: insights into the potential of various iron therapies to induce oxidative and nitrosative stress. Free Radic Biol Med 65:1174-1194. https://doi.org/10.1016/j. freeradbiomed.2013.09.001

70. Chang HC, Wu R, Shang M, Sato T, Chen C, Shapiro JS, Liu T, Thakur A, Sawicki KT, Prasad SV, Ardehali H (2016) Reduction in mitochondrial iron alleviates cardiac damage during injury. EMBO Mol Med 8(3):247-267. https://doi.org/10.15252/ emmm. 201505748

71. Archer SL, Marsboom G, Kim GH, Zhang HJ, Toth PT, Svensson EC, Dyck JR, Gomberg-Maitland M, Thebaud B, Husain AN, Cipriani N, Rehman J (2010) Epigenetic attenuation of mitochondrial superoxide dismutase 2 in pulmonary arterial hypertension: a basis for excessive cell proliferation and a new therapeutic target. Circulation 121(24):2661-2671. https://doi.org/10.1161/CIRCU LATIONAHA.109.916098

72. Niihori M, Eccles CA, Kurdyukov S, Zemskova M, Varghese MV, Stepanova AA, Galkin A, Rafikov R, Rafikova O (2019) Rats with human mutation of NFU1 develop pulmonary hypertension. Am J Respir Cell Mol Biol. https://doi.org/10.1165/rcmb.2019-0065O C

73. Viethen T, Gerhardt F, Dumitrescu D, Knoop-Busch S, ten Freyhaus H, Rudolph TK, Baldus S, Rosenkranz S (2014) Ferric carboxymaltose improves exercise capacity and quality of life in patients with pulmonary arterial hypertension and iron deficiency: a pilot study. Int J Cardiol 175(2):233-239. https://doi. org/10.1016/j.ijcard.2014.04.233

74. Frise MC, Cheng HY, Nickol AH, Curtis MK, Pollard KA, Roberts DJ, Ratcliffe PJ, Dorrington KL, Robbins PA (2016) Clinical iron deficiency disturbs normal human responses to hypoxia. J 
Clin Investig 126(6):2139-2150. https://doi.org/10.1172/JCI85 715

75. Busti F, Marchi G, Girelli D (2019) Iron replacement in inflammatory bowel diseases: an evolving scenario. Intern Emerg Med 14(3):349-351. https://doi.org/10.1007/s11739-019-02043-1

76. De Franceschi L, Iolascon A, Taher A, Cappellini MD (2017) Clinical management of iron deficiency anemia in adults: systemic review on advances in diagnosis and treatment. Eur J Intern Med 42:16-23. https://doi.org/10.1016/j.ejim.2017.04.018

77. Brugnara C, Adamson J, Auerbach M, Kane R, Macdougall I, Mast A (2013) Iron deficiency: what are the future trends in diagnostics and therapeutics? Clin Chem 59(5):740-745. https://doi. org/10.1373/clinchem.2012.182071

78. Bregman DB, Morris D, Koch TA, He A, Goodnough LT (2013) Hepcidin levels predict nonresponsiveness to oral iron therapy in patients with iron deficiency anemia. Am J Hematol 88(2):97101. https://doi.org/10.1002/ajh.23354
79. Ruiter G, Lanser IJ, de Man FS, van der Laarse WJ, Wharton J, Wilkins MR, Howard LS, Vonk-Noordegraaf A, Voskuyl AE (2014) Iron deficiency in systemic sclerosis patients with and without pulmonary hypertension. Rheumatology (Oxford) 53(2):285-292. https://doi.org/10.1093/rheumatology/ket331

80. Decker I, Ghosh S, Comhair SA, Farha S, Tang WH, Park M, Wang S, Lichtin AE, Erzurum SC (2011) High levels of zincprotoporphyrin identify iron metabolic abnormalities in pulmonary arterial hypertension. Clin Transl Sci 4(4):253-258. https:// doi.org/10.1111/j.1752-8062.2011.00301.x

Publisher's Note Springer Nature remains neutral with regard to jurisdictional claims in published maps and institutional affiliations. 